\section{THE NURSERIES OF CHOLERA.}

An Address delicered before the Section of Public Medicine of the British Medical Assuciation at Neucastle, August, 1893.

By ERNEST HART, D.C.L.,

Clıairman of the Parliamentary Bills Committee.

(Continued from p. sis.)

IV.-MECCA AND IT'S MARTYRE.

WE must now turn our attention to another great religious festival-a different religion, a different people, a concourse drawn together from a far wider area, but one which, like the Hardwár fair of old, has become a focus and a diffusion point of cholera, a cause of death and disaster to the pilgrims, and of danger to the world.

\section{A Prrilous Pilgrimage.}

Shut up in our insularity, and taught to believe that Christianity and the civilisation with which it has of late centuries been associated are the great motive forces of the world, we are too apt to forget the power of that other religion which for so many centuries was the great competitor with Christianity. The wars between the Crescent and the Cross occupied the Middle Ages, and the standard of Islam stills blocks the way against the Christian country which possesses the largest army in the world. Mohammedanism is not dead, and Islam still remains the faith of 200 millions, or 14 per cent., of the human race-a faith which is absolute and obedient, and which leads intelligent men, men of position and whose lives are cast in pleasant places, to suffer pains and discomforts which to an ordinary dulettante Christian would be absolutely intolerable, rather than break the commandments. Among the ordinances, which to the faithful are commands, is that of pilgrimage to Mecca. From Turkey, from a belt of country extending eastwards across Asia to the farthest confines of Malay, and from the whole of Africa, pilgrims set out every year, turning their steps towards Mecca in obedience to this command. Many fall sick by the way, many die; from about 60,000 to 100,000 each year attain their end, months, and sometimes years, having been devoted to the task, and sufferings and hardships undergone which it would be difficult to describe. This intensity of faith must be remembered if we are to realise the frame of mind of those educated men who, to our undisguised surprise, are found willing to submit not only to the perilous and weary journey, but to the dirt, the danger, the extortion, and the rascality of the final act-their residence in the holy city. To many of them this is but a flea-bite after what they have gone through, and with Paradise in sight they will not draw back, after suffering so much, even if to advance mean martyrdom. Moreover, it is but for once, and when the Hajji has returned to his native country his personal interest in reform is slight. The Meccans therefore hold the key to the position, and do much as they please, allowing their city to become a pest-house, a centre where infection can intensify, and whence it can be spread by returning pilgrims over the whole world.

\section{" Where ONILY MaN is Vile."}

Mecca, the birthplace of Mohammed, stands in a narrow valley sixty-five miles from Jiddah, its port, on the Red Sea. The country close around is barren, and for provisions the inhabitants have to depend on importation from a distance. It has, however, a plentiful supply of water. From the times of earliest history it has been a trading centre, and long before the time of Mohammed was esteemed a holy place, possessing sacred objects which repaid a pilgrimage. Although the modern pilgrimages, then, with which we have now to do are performed in obedience to the commands of Mohammed, it may be doubted whether the customs of the place and the details of the observances are not, in many cases, survivals of practices which were current long before the origin of Islam. The city itself is mostly modern, having been frequently devastated by winter torrents from the hills around; the streets are, for an Eastern city, broad and airy, but unpaved and filthy. Drainage does not exist; water there is in plenty. The population is about 60,000 , and is mainly supported by the proceeds of the annual pilgrimage and by the manufacture of sacred relics. Compared with the problem of dealing with an Indian fair, the purification of Mecea would seem by no means an insuperable difficulty. Clean dry rocks, pure water, and a blazing desiccating sun are the materials on which we have to work. Man, and man only, is the difficulty. No infection need defile the water, which constantly flows through the underground conduit from the mountainous district beyond Aráfa ; no local disease need reappear in the food, which all comes from afar; no difficulty need be found in dealing with filth, which, buried in the sand, quickly dries up into a harmless powder, and might be made by degrees to fertilise the arid soil. The inhabitants, however, choose to live crowded together and to surround their houses with refuse and filth; they choose to foul the water supply, and from immemorial usage they regard the pilgrims as victims to be fleeced rather than as co-religionists to be protected. The result is that, while Mecca may be well enough suited for the Meccans in ordinary times, it is not in any way prepared for the strain which comes upon it during the annual pilgrimage, and if a disease such as cholera be then introduced, it straightway spreads like wildfire. If, however, we inquire how it spreads, by what means the infection is distributed, we find that here, as in India, and everywhere else, the main factor, the constant cause, is the drinking of cholera-polluted water.

\section{At Hagar's Well.}

The proceedings of the pilgrims themselves, the ritual gone through by them during their stay, none of which they like to miss, little as their meaning may be understood, also tend to the spread of the disease, if once it be implanted among them. The march to Arafat, the night spent there in devotion or in the crowded coffee booths, the "stand" by the Hill of Mercy, the rush to Mina, the sacrifices, the fearful stench from the thousands of slaughtered animals, the tawaf, or sevenfold circuit of the sanctuary, each of the many thousand pilgrims kissing the black stone as he passes, the blazing heat, the intolerable thirst, the religious fervour which leads them to accept everything as holy. which belongs to Mecca, all drive the unfortunate pilgrims to the consumption of the vilest fluids under the name of water. The ground is defiled, there is no attempt at conservancy, the wells are poisoned by filth, and, if that happens to be choleraic, cholera breaks out. One of the observances is especially dangerous. Next to the Ka'ba the principal point of interest in the Mosque is the Well Zemzem, a deep shaft said to be the source from which Hagar drew water for her son Ishmael. The pilgrims are many, the well, however, is but one, and its water not plentiful at the best. Yet everyone wishes to drink and to bathe in these miraculous waters. Each pilgrim in turn, stripped to the waist, stands beside the well while a bucket of the water is poured over him; of this he eagerly drinks as it flows from the bucket, the rest flowing over his naked body, soaking through his loin cloth, and streaming back into the well to be used again. His place is immediately taken by another and another, and so on, each drinking the washings of the rest. Can we wonder then that this water, on analysis, is found to have the characteristics of bad specimens of sewage, or that after the pilgrimage is over the roadside should be found strewn for a grimage is over the dead bodies of the faithful, killed by a draught of dirty water, after all the difficulties and dangers they have overcome? There is a bathos about it which would appeal almost to one's sense of humour where it not so serious an affair.

\section{A Ghastly Spectacle.}

This is an actual business of to-day. I am not speaking now of things which happened years ago. From June 8 th th June 25th, 1893, there were 2,201 deaths at Mecca; and on one day (June 26th) there were 499 at Minah and 500 at Mecca, making in one day 999 deatls. From June 26 th to July 24 th there were 499 deaths at Minah, 3,408 at Mecca, and 303 at Jiddah. I have an account of the state of Mecca, written by Dr. Chaffey, an Egyptian Moslem, sent by the Quarantine Board as their sanitary correspondent to Mecca, which reveals a ghastly state of things happening, one may 


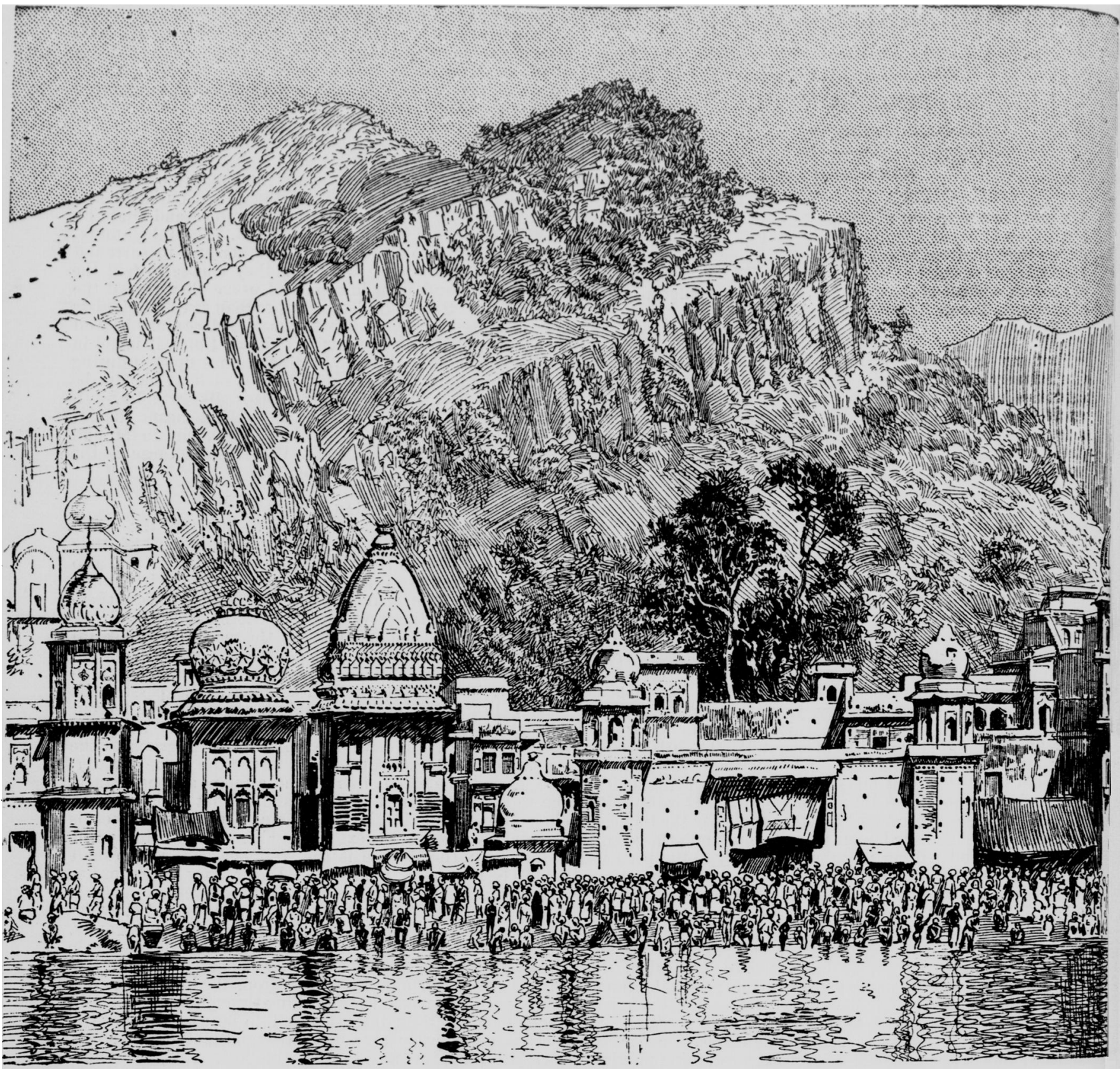

A Panoramic View of Hardwár

say, almost at the door of Europe, taking account of these days of rapid steam communication. Dr. Chaffey says :

On arrival at Mecca I commenced at once an inspection of the town. The hospital, private houses, and tents were full of people suffering from cholera. I sent you by telegraph the number of deaths declared officially but on account of the extraordinary mortality it must be admitted that the number of deaths could not be precisely known, and it may certainly be considered to be double that officially declared, even more. At Moona it was impossible to bury all the dead, who lay here and there in heaps. Round about the Syrian Caravan (Mahmal) there was a large number of bodies lying unburied. Returning from Moona to Mecca I found the route strewn with dead. In the town of Mecca itself dead bodies were jying about in a state of putrefaction, and when they were at last transported to the cemetery they were thrown down there, and left lying for ported to the cemetery they were thrown down there, and left lying
days unburied, from want of a sufticient number of gravediggers.

A Danger to the Wori.d.

The whole affair is horrible. The place is a slaughterhouse, where the best men of the Mohammedan world are being every year destroyed. For it must be borne in mind that the injunction to visit Mecca is not imposed on everyone, but on those only who are able to devote the time and able to provide for their families while away. We make a great mistake if we class the Meccan pilgrims with the poor, the miserable, and the helpless; the cream of the faithful go to Mecca, and as years go by and the knowledge spreads that cholera is a preventable disease, a mere filth disease, spread by dirty customs and dirty water, Mohammedans are awaking to the fact that their best men are being gratuitously sacrificed, and from sheer ignorance and stupidity exposed to a danger never contemplated when the duty of pilgrimage was imposed upon them. But no nation, no part of the world can isolate itself or afford to stand aloof from the rest. This is not a mere Mohammedan question; what is a danger to the pilgrims is a danger also to the world ; for it is through Mecca and its pilgrims that cholera spreads to Egypt, and thus to all the ports of Europe. 


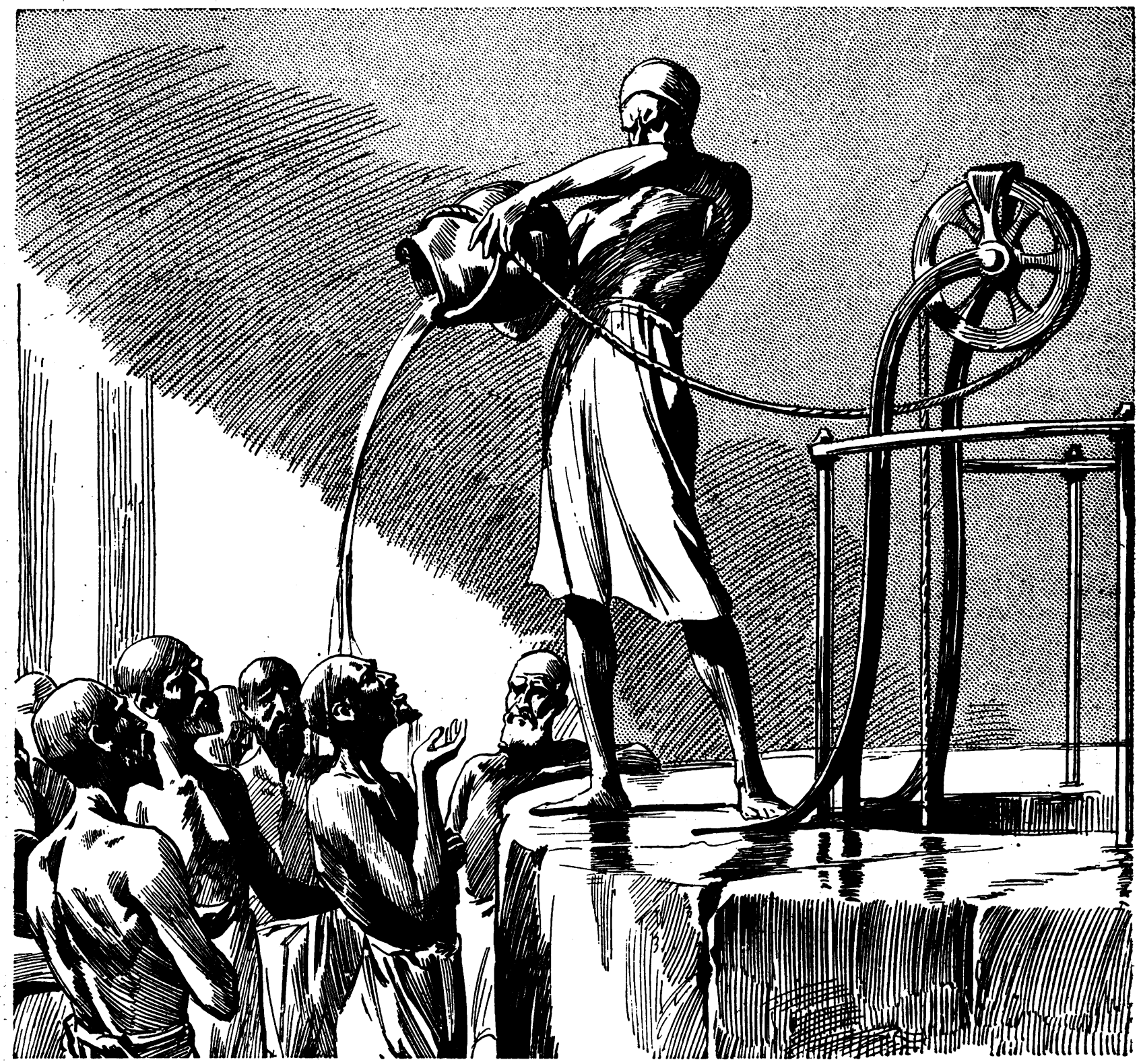

Pilgrims at Zemzem, the Reputed "Hıgar's Well " at Mecca.

V.-CONCLUSIONS.

The infection of cholera does not fly about haphazard in the air; it does not go where it listeth; it has no voice in the decision whether it shall live and destroy or shall perish and be harmless ; it cannot jump across open spaces, and when it moves from place to place is always carried, and mostly carried by man. It is, however, a living thing, and by the act of living produces the disease; within man's body it multiplies exceedingly, it is carried by him to fresh districts. Outside the body, however, it is passive and, although it may grow, cannot force its way into man again, and would in tine die out if man were but careful not to swallow it. Thus it happens that when cholera travels it always follows lines of human communication, one person after another carrying it_a step further on its journey.

\section{Limits of INFECTION.}

Now, suppose we grant for a moment that cholera is helplessly and hopelessly endemic in certain parts of India-a thing which I will not readily grant, belicving as I do that 8 what is endemic is the habit of drinking dirty water-but. supposing that we grant so much, it still can travel out of its endemic home only so far as a man can carry it before he drops from the disease. This distance is increasing every year owing to railways and steamboats transporting the infected $\mathrm{m}$ an a longer distance during the period of incubation ; but, be the distance long or short, the disease would halt at the end of the first stage of its journey, unless the infection there were again swallowed by the healthy, and thus again carried forward another stage by another porter. The continued existence of an endemic area is doubtless a reproacl to the sanitation of India, but so also is the repeated sprea I of the disease a reproach to the civilised nations among whom it so easily takes root, for it never would take root at all but for the prevalence of the filthy custom of drinking contaminated water. Some time, perhaps, cholera may be rooted out of its home; but that certainly will not happen in our generation, involving, as it will, a complete revers $u$ of the habits of a people the very keynote to wh ose existence is custom and tradition. 
Mecca the Centre of Infection.

England, however, is not standing idle in the matter. Sanitation is everywhere a department of Indian State administration, and every province has a sanitary commissioner, with his subordinate staff. The larger municipalities are expending large sums in obtaining pure water supplies, their example is gradually permeating the smaller communities, and a constant pressure is being brought to bear on the villages to avoid pollution of their wells and tanks. It is, however, a slow business with so vast a country, inhabited by so many diverse races. Meanwhile the teaching of the Kumbh fair at Hardwár in 1891 is not likely to be thrown away, and it is probable that in time the progress of cholera northwards, its old route to Europe, will be brought under control. It is hopeless, however, to look for any improvement in the Red Sea route so long as Mecca remains as it is. We hope to check the progress of cholera towards Afghanistan and Persia by carefully guarding the sanitation of the northern fairs; we dare not, however, expect to see its progress towards Egypt and the South of Europe materially checked until the authorities responsible for it will equally carefully guard the sanitation of Mecca. It is not by quarantining the pilgrims and setting up a series of lazarettos, which themselves become fresh centres of infection, that cholera can be stopped, but by looking after the pilgrims' resting places, and rendering them so clean that if cholera arrive it shall not spread, and shall not set out again on its forward march. Mecca is the place in which to stop the cholera. From every point where cholera can originate pilgrims set out, each of whom may bring with him the infection. All pilgrims, however, go to Mecca, where they wait time enough to trap the cholera and render it harmless if Mecca were but a cleanly place. Again, when the days of pilgrimage are over, the hajjis set out on their return, radiating from Mecca to every quarter of the compass, and carrying such infection as they may have gained. This, however, is not now the infection which was brought from India, but a fresh generation, born at Mecca, which would never have come into existence at all but for the uncleanliness of the place. Mecca, then, is the one place where one can put the foot down firmly upon cholera, whether coming in or going out. If the disease arrives at all, it comes there one by one; but it goes out by thousands, and it is giving it an enormous start to let it get to Egypt before it is interfered with. Egypt is practically part of Europe.

\section{An Appeat to Mohammedans.}

At the present time the precautions taken seem chiefly to consist of supervision of the Indian pilgrims, who are presumably the sources of infection, and their isolation at Kamaran, when disease appears among them during their voyage from Bombay, and, as regards the returning pilgrims, their so-called quarantine by the Egyptian authorities at El Tor. I cannot find that any systematic precautions are taken in reference to the great numbers who return to their homes by the various caravan routes which converge on Mecca, and it is clear that no amount of quarantine by sea, even if itself successful, can ever be a protection so long as Mecca remains a nursery of cholera and disseminates the disease by caravan. Mecca is the centre to which it converges, and from which in turn it scatters, and Mecca must be made clean. The whole district lives by the pilgrims. The least it can do after taking their money is to spare their lives. The difficulty is, who is to undertake the work? The Suzerain is the Sultan, who, being the religious head of the Mohammedan world, would probably hesitate to incur the odium of being dictated to by the Christian Powers in such a matter. The actual ruler is the hereditary Sheriff of Mecca, who is so firmly fixed in his position that the Sultan might well decline to enter into conflict with him, risking, as he certainly would thereby, a split among his followers. Direct interference by any single European Power is hopeless. Any Government making the attempt would soon find itself involved in the mazy labyrinths of the Eastern question. To wait for the spread of education in sanitary matters to such dark places is to wait till doomsday. No; the only person who can usefully interfere is the Sultan, but to interfere with efficacy he must be supported by a strong backing of Mohammedan opinion. This can only be done by the united action of the leading men in the various centres of that religion. If they can be brought to acknowledge, not only the greatness of the evil, which by personal and family experience they know well enough, but the direction in which the true cure lies, there may be hope of some action being taken. In the meantime the Powers might well unite, not perhaps to urge the Sultan, but to make his action easy, and to put no obstacles in his way; and England, great Mohammedan Power that she is, mightwell do all that is possible to lighten the lot of those unfortunate pilgrims who, for the sake of Europe, are isolated at Kamaran. If inspection is to be effectual, it must not be rendered hateful to those who are inspected; and, knowing the feelings of Mohammedans about their women, we might well afford to provide the Indian pilgrim service with some female doctors. The aim should be in all things to obtain the hearty co-operation of the Mohammedans themselves. If this were obtained Mecca, instead of being a place of rest and refreshment for cholera infection, might become a sanitary barrier which it could not pass.

What Should Be Done.

Let me then formulate the steps which ought to be taken to save the Mohammedans from the danger caused by their pilgrimages, to save the world from the danger caused by Mecca :-

1. The Indian sanitary services should be reorganised on the following basis:

(a) An Imperial sanitary department attached to the Government of India.

(b) A provincial sanitary department attached to each of the provincial governments, such as Bengal, North West Provinces, Punjab, Madras, Bombay, Central Provinces, etc.

(c) A local sanitary department attached to each municipality, district board, etc.

(a) The Imperial sanitary department should be administrative and scientific, and quite distinct from the sanitary department of the army. It should consist of (1) the Sanitary Commissioner with the Government of India ; (2) a deputy sanitary commissioner; (3) a medical statist; (4) a veterinary commissioner; (5) a sanitary engineer; (6) a Minister of Health, having a seat in the Viceroy's Council, as president. Scientific agents : Laboratory with trained experts. Duties: The advising of the Viceroy and Council on important health matters, either initiated by the Imperial sanitary department, or referred to it by the local governments; the collection and publication of information as to epidemic disease existing in lindia and in other countries; the right of asking from provincial governments what they propose to do, or have done, in checking or inquiring into diseases affecting man, animals, or agriculture in their provinces; the arranging that all administration reports shall be drawn up on a uniform plan for ready reference; the acquiring of all information regarding the movements of pilgrims, coolies, and emigrants, and the advising the provincial governments, and requiring the latter to take proper precautions; the consideration of new sanitary laws, etc.

(b) The provincial sanitary department should consist of the following sanitary officers appointed by the local government: (1) Sanitary commissioner; (2) assistant sanitary commissioner; (3) sanitary engineer ; (4) a president, who should be a high officer in the Civil Service. Travelling agents: Deputy sanitary commissioners or inspectors, veterinary surgeons, deputy sanitary engineers, as may be required. Scientific agents: Trained professors and assistants in government laboratory for bacteriological, chemical, agricultural work, etc., and general sanitary investigations requiring to be done in laboratory. Duties: To control local authorities; to institute special investigations at any particular spot on any particular subject; to make by-laws and amend sanitary laws; to investigate diseases of men and animals, and study agricultural pests, etc; to analyse waters, etc.

(c) Local sanitary departments to consist of municipal commissioners or district magistrates, with civil surgeon when obtainable. Executive agents: A health officer, at tached to one or more towns; an engineer in a similar position, and a sanitary staff for each place as required. Duties:Conservancy, water supply, building regulat:0.2s, drainage: 


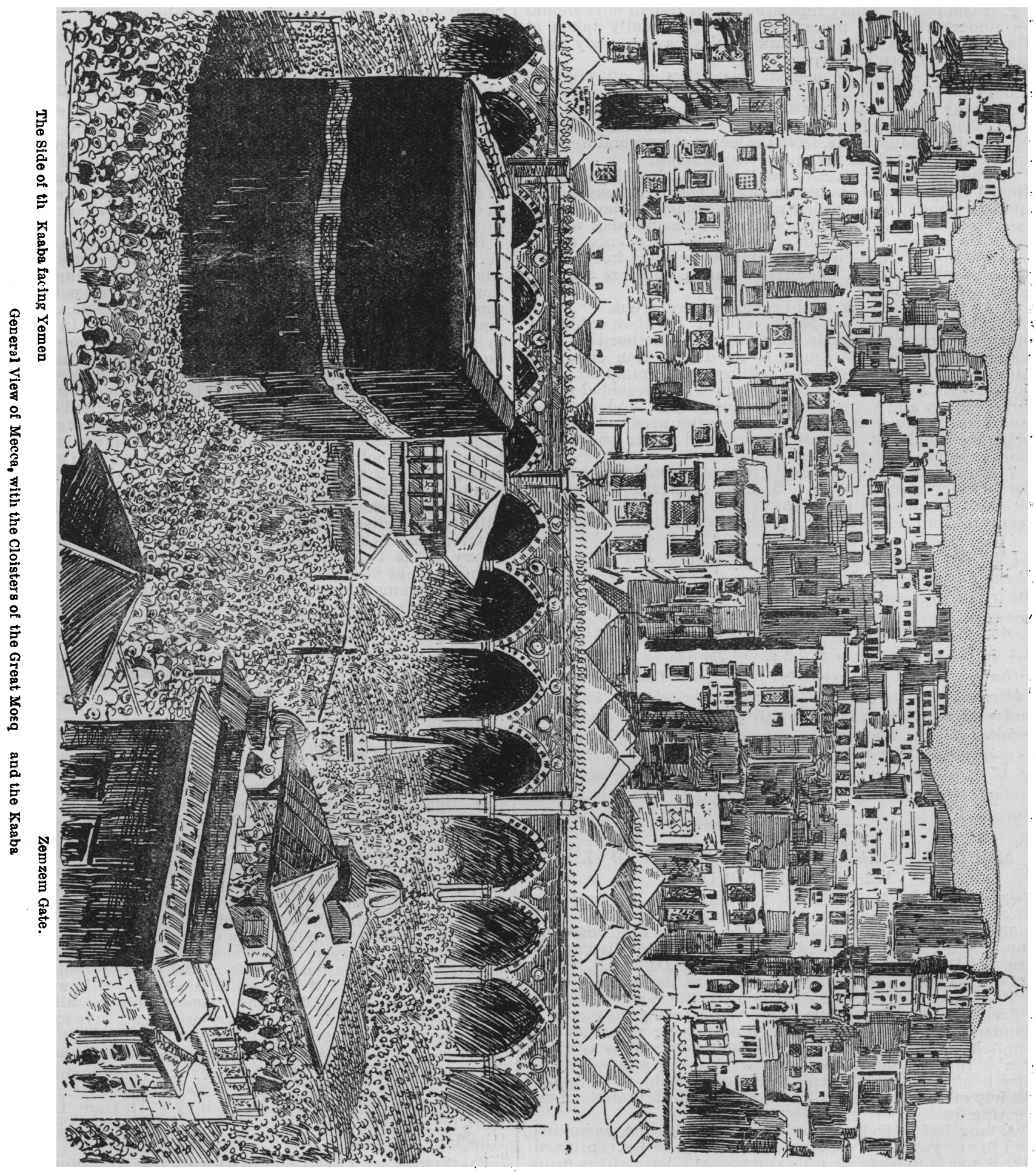


registration of births and deaths, vaccination, stamping out of infectious disease, and informing provincial authority by weekly reports as to prevalence of cholera, small-pox, or other dangerous disease.

2. A complete sanitary regulation of all Indian fairs should be undertaken, the precautions so successfully taken at Hardwár in 1891, of which full details have already been given, being taken as a type.

3. A rigid system of medical inspection of all pilgrims should be instituted at the ports from which they start, the sick being detained, and the healthy alone allowed to proceed. This, it may be added, would be all the more effectual in regard to Indian ports, from the fact that a second weeding out of the infected can take place at Kamaran.

4. The medical inspection at Kamaran should be so conducted as to ensure its complete efficiency. Among the inspectors should be qualified-medical women, without whose assistance the medical inspection of Mohammedan women must be either a farce or a great cause of offence, and if possible these medical women ehould be selected from among Mohammedan women doctors, of whom numbers are now educated in India.

5. At Jiddah the sick would again be weeded out.

6. The sanitation of Mecca should be thoroughly reorganised under the auspices of the Turkish authorities. The water supply from its source to its distribution should be carefully inspected and protected from contamination. The poison well Zemzem should be cleaned and provided with a larger supply and a continued change of water, and the most complete precautions taken that the water used to bathe the pilgrims should at once run away, and under no circumstances return to the well

7. During the time of the pilgrimage a complete system of conservancy should be carried out on the Hardwar plan, the strictest precautions being enforced to ensure the immediate removal of all refuse and the prompt isolation of all sick.

[M. Hanotaux, Minister Plenipotentiary and delegate of France to the International Sanitary Conference now sitting in Paris, having stated that the substance of this addres.s and the recommendations contained in it afforded the basis for the propositions to be submitted to that Conference, it has seemed desirable to publish in these columns the full text of the address, which has not hitherto appeared in any medical periodical in this country. The address at the time of its delivery was extensively reported abroad and in the columns of the "Daily Graphic," to which paper we are indebted for the illustrations accompanying it. Copies of these have been deposited by request in the International .Medical Library of the United States at Washington, together w.th maps illustrating the progress of cholera during the several epidemic years since 1840.]

\section{MEDICAL SICKNESS, ANNUITY, AND LIFE ASSURANCE SOCIETY.}

Tur usual monthly meeting of the Executive Committee of this Society was held on February 15th. The chair was taken by Dr. de Havilland Hall, the Deputy Chairman, and there were also present Dr. J. Pickett, Mr. J. Brindley James, Mr. H. H. Clutton, Dr. Major Greenwood, Dr. A. S. Gubb, Dr. W. Knowsley sibley, and Mr. Edward Bartlett.

The accounts presented showed that the Society had received 21 proposals for new membership during the month of January, and in addition 15 of the existing members had applied to have their benefits increased. This is about double the average number of new proposals, and is satisfactory evidence that the efforts recently made to bring the society more prominently before the medical profession are bearing fruit.

A long list of sick claims was presented and examined, and in every case the sick pay was ordered to be continued. Seven special reports were also presented relating to as many c sses of chronic illness, and their contents left little hope tiat any of these members would ever be able to resume their professional work.

The Secretary reported that the valuation of the business was being proceeded with, and it is hoped that some of the resnlts will shortly be before the Committee.

Prospectuses and all information may be obtained on application to Mr. F. Addiscott, Secretary, Medical Assurance Society, 33, Chancery Lane, london, W.C.

\section{THE GREENWICH EXPLOSION.}

Nature of the External Injuries in the Case of Martial Bourdin. WE are enabled to publish the following authentic details as to the nature of the injuries received by the man Martial Bourdin. His age was stated to have been 22 , but he appeared to be four or five years older. He was admitted to the Seamen's Hospital, Greenwich, on Thursday, February 15th, at 5.15 P.M., having been found about half an hour previously in Greenwich Park in a state of collapse, and suffering from injuries caused by a loudly detonating explosive.

The patient, who had been tended before admission by $\mathrm{Mr}$. W. Willes, was at once seen by Mr. Jervis, the house-surgeon, who found him profoundly collapsed, and in a dying condition. The surface was cold, and the face very pallid and spotted with blood. There was much restlessness, and the man was barely conscious. The only remark made in answer to inquiries was that he "felt cold." There was no smell of burning, but a strong acid odour, like that of acetic acid, was distinctly perceptible on removing the clothes. The contents of the pockets, which consisted of printed and written papers and some money in gold and silver, were intact, but stained with blood. There had evidently been much bleeding before admission, as the clothing was saturated. The left hand had been almost wholly removed, the forearm presenting a ragged stump, from the open extremity of which.protruded fragments of carpal bones and long tendons, mostly flexors, which were still attached to their muscles. The edges of the torn skin were not discoloured.

After removal of the clothes, the chief external marks of injury on the trunk were presented in the upper part and right side of the abdomen. In the middle line in front, between the umbilicus and the top of the sternum, there was an oval wound which measured two inches from above downwards, and one inch and a half from side to side. To the right of this were two smaller and more superficial wounds, and in the right lumbar region, just below the last rib a small but deep and penetrating wound with everted edges. In the first of these wounds-that in the middle line-omentum and intestine were freely exposed, and from this and the wound in the lumbar region there was before death an escape of gas and blood. There were several large black eschars on both thighs and on both sides of the abdomen. The patient died at 5.40 P.M. . The body was that of a short but welldeveloped and fairly muscular man, with small hands and feet, light hair, and a long moustache. The details of the post-mortem examination, which was made on Saturday. February 17th, at 1 P.M., will be given in full at the adjourned inquest on Monday next, but we are in a position to state that the internal injuries revealed at the post-mortem examination were such as might have been anticipated on examination of the surface of the body. There was a large rent of the duodenum, and the liver and right kidney were mucl torn. No metal nor foreign body of any kind was found in the abdominal cavity at the post-mortem examination. There were several wounds on the thighs and on the front of the trunk, from some of which small pieces of cloth were extracted. Beyond some firm and extensive pleural adhesions on the right side, no signs of injury or disease were found in any other internal organ.

Professor Theodor Prschmann, of Vienna, author of $A$ History of Medical Education fiom the most Remote to the most Recent Times (translated into English by E. H. Hare, Lond'n. 1891), is mentioned as likely to succeed the late Professor Hirsch in the chair of Histury of Medicine at Berlin.

Pastenrism at Padua.-Statistics of the Antirabic Inst: tute of Padua, of which Dr. De Giovanni is Director, re. cently published by Drs. Zaniboni and Bonetti, show that in 1891 the total number of persons treated was 57 , nd in 1892, 48. No death occurred in either serics. 